\begin{tabular}{ll}
\hline 臨 & 床 \\
\hline
\end{tabular}

\title{
脊髄小脳変性症の visual suppression test
}

一神経耳科学的検査との関連について一

水野 正浩・山根 雅昭* ・小山内龍一*

\section{Visual Suppression Test in Spinocerebellar Degenerations}

-In Association with Neurotological Examinations--

Masahiro Mizuno

(University of Tokyo)

Masaaki Yamane and Ryuichi Osanai

(Tokyo Metropolitan Neurological Hospital)

Visual suppressions of caloric nystagmus was studied in 86 patients with spinocerebellar degenerations in association with other neurotological examinations.

In 16 of the patients, caloric nystagmus was normally suppressed by visual fixation, while in 41 it was not suppressed, and in 19 it was even enhanced by visual fixation. In 10 , the influence of visual fixation on caloric nystagmus could not be evaluated because of deficient caloric nystagmus or of disturbance of the quick phase of nystagmus.

The presence of gaze nystagmus and/or rebound nystagmus was closely correlated with the incidence and degree of the disturbance of visual suppression. Also, disturbance in pursuit eye movement, saccadic eye movement and optokinetic nystagmus was related to that of visual suppression. The presence of positional nystagmus or positioning nystagmus, however, was not related to disturbance of visual suppression.

On the basis of our study of visual suppression, the significance of positional and positioning nystagmus tests was considered to be somewhat different from that of other neurotological examinations.

Key words: spino-cerebellar degeneration, visual suppression test, neurotological examination

はじめに

前庭動眼反射の中枢性制御機能検査である visual suppression test（以下 vs test と略）は, 中枢神経系の機能検査として広く神経耳科領域 で行われている
小脳変性症（以下，脊小変と略）における vs test の結果と臨床像との関連について報告し た ${ }^{2)}$. 本稿においては, vs test と他の神経耳科 学的検査結果との関連にういて検討したのでて れを報告する。 


\section{対象と方法}

対象症例は前回 ${ }^{2)}$ と同じ脊小变症例86例であ る. 男 40 ，女46症例で，年齢は，15～79歳（平 均49歳）である。乙のうち遺伝性のものは33例 である. 病型については Greenfield の分類に 従えば，小脳型 9 , 脊䯣小脳型 69 , 脊䯣型 4 , その他 4 である. vs test は竹森の方法に従って 行(3)，結果の判定は, vs が30\%を超えるもの を正常，30\%から 0\%を vs の減弱ないし消失， 一X\%を明所眼振増強型とした. 温度眼振反応 の高度低下や急速相の障害のため vs の判定が 出来なかった例は判定不能とした。

vs test 以外の神経耳科学的検查としては，以 下に述べる項目を行い, vs test との関連を検討 した.

\section{1) 体平衡検査}

直立検査を行いその結果を, 開閉眼とも動摇 を認めぬものを正常, 閉眼で動摇著明のものを + , 開眼でも動摇著明のものを\#とし，さらに
起立不能をあわせて 4 群に分類した.

\section{2 ) 眼振検查}

注視，頭位，頭位変換眼振検査を行った。な お，反撥眼振 Rebound Nystagmus の有無之 vs test との関連についてあ検討した.

3 ) 視刺激検査

視標追跡検査 (ETT) は水平 $30^{\circ}, 0.3 \mathrm{~Hz}$ の視 刺激を与え，得られた $\mathrm{ENG}$ 記録より結果を， 正常, saccadic, dysmetric に分類したが，一部 に追従不能のものがあり，検査不能とした．

急速眼球運動 (saccade test) は水平 $30^{\circ}, 0.3$ $\mathrm{Hz}$ にて刺激を与え，その結果を，正常，dysmetric，速度低下に分類した。

視運動性眼振検査は, OKP test を行い，その 結果を, 最高緩徐相速度 $60^{\circ} /$ 秒以上を正常, $30^{\circ} /$ 秒以上を軽度〜中等度障害， $10^{\circ} /$ 秒以上 を高度障害，ほとんど眼振解発のみられぬむの を無反応とした。

表 1 平衡障害と vs

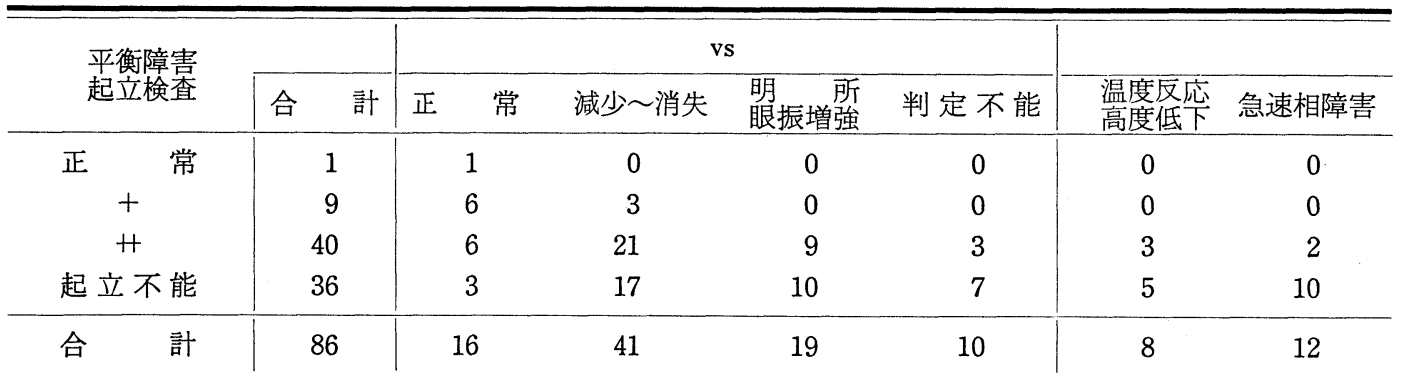

表 2 注視眼振とvs

\begin{tabular}{|c|c|c|c|c|c|c|c|}
\hline \multirow{2}{*}{ 注 視 眼 振 } & & \multicolumn{4}{|c|}{ vs } & \multirow[b]{2}{*}{$\begin{array}{l}\text { 温度反応 } \\
\text { 度低下 }\end{array}$} & \multirow[b]{2}{*}{ 急速相障害 } \\
\hline & 合計 & 正常 & 減少～消失 & $\begin{array}{l}\text { 明所 } \\
\text { 眼振増強 }\end{array}$ & 判定不能 & & \\
\hline$(-)$ & 27 & 13 & 9 & 3 & 2 & 0 & 4 \\
\hline$(+)$ & 59 & 3 & 32 & 16 & 8 & 8 & 8 \\
\hline 定方向性 & 2 & 0 & 2 & 0 & 0 & 0 & 0 \\
\hline 左 右 注 視 & 30 & 3 & 16 & 9 & 2 & 2 & 4 \\
\hline 完 全 注 視 & 19 & 0 & 8 & 6 & 5 & 5 & 4 \\
\hline 垂 直 性 & 8 & 0 & 6 & 1 & 1 & 1 & 0 \\
\hline 合計 & 86 & 16 & 41 & 19 & 10 & 8 & 12 \\
\hline
\end{tabular}




\section{結果}

vs test の結果は正常 $16 ，$ 减少〜消失 41 ，明所 眼振増強19, 判定不能10であった. 86例のうち, 温度眼振反応高度低下～消失例が 8 , 急速相障 害例が10あり, vs test の判定不能例の原因とな っていた。

1）体平衡障害（起立検査）とvs test 結果 との関係を表 1 亿示す，起立検査で正常または 十の軽度障害群では, vs の異常は少ない。開眼 時にも動摇著明のHや起立不能の群ではvs の 異常は高率に検出され, 温度反応高度低下や急 速相障害もみられた。平衡障害の程度に比例し て, vs の異常の頻度と程度が増すと考えられる.

2）眼振とvs test 結果との関連について.

注視眼振とvs test 結果との関係を表 2 に示 す. 注視眼振のみられなかった群ではvs 手半 数においては正常であったが，急速相障害が 4 例に認められた。注視眼振のみられた群では95
\%以上の例において vs の異常が認められた. 注視眼振の内訳との関連では，完全注視方向性 や垂直性眼振のみられたものでは, vs の異常の 頻度が高く, vs の障害も高度であった。注視眼 振とその程度は, vs の障害の程度, 頻度と比例 すると考えられた。

反撥眼振 (Rebound Nystagmus) と vs test 結果との関係を表 3 に示す. 反撥眼振のみられ ない群では約30\%の例において vs は正常であ ったが，急速相障害はむしろこの群に 8 例と多 かった，反撥眼振のみられた群では全例がvs の異常を示した.

頭位眼振とvs test 結果との関係について表 4 亿示す。頭位眼振のみられた群にvs の異常 がやや多い。 しかし，温度眼振反応高度低下や 急速相障害による判定不能例は，頭位眼振のみ られない群にむしろ多いことは注目される。頭 位眼振の内容とvsとの関連は明らかではない。

表 3 反撥眼振とvs

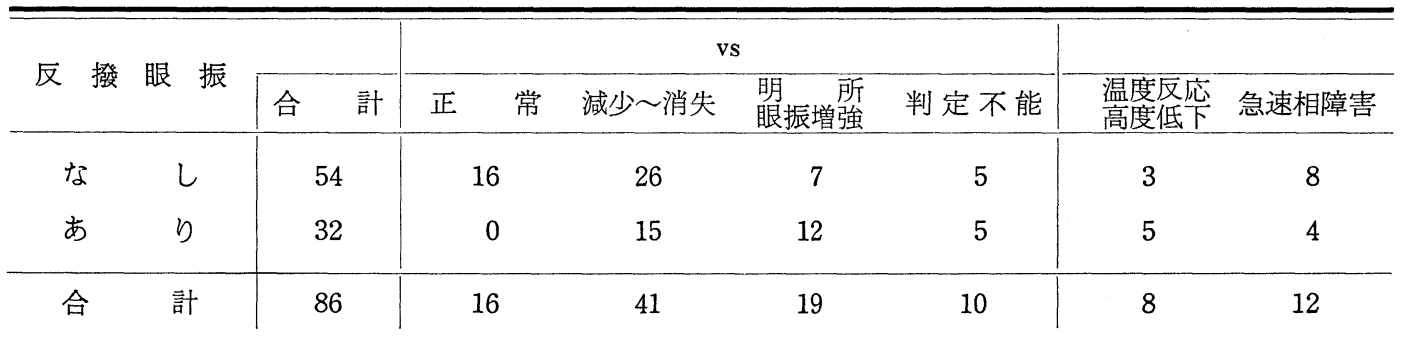

表 4 頭位眼振とvs

\begin{tabular}{|c|c|c|c|c|c|c|c|}
\hline \multirow{2}{*}{ 頭 位 眼 振 } & & \multicolumn{4}{|c|}{ vs } & \multirow[b]{2}{*}{$\begin{array}{l}\text { 温度反忘 } \\
\text { 高度低下 }\end{array}$} & \multirow[b]{2}{*}{ 急速相障害 } \\
\hline & 合計 & 正 & 減少～消失 & $\begin{array}{l}\text { 明 所 } \\
\text { 眼振増強 }\end{array}$ & 判定不能 & & \\
\hline$(-)$ & 32 & 9 & 9 & 7 & 7 & 5 & 9 \\
\hline$(+) *$ & 54 & 7 & 32 & 12 & 3 & 3 & 3 \\
\hline $\begin{array}{l}\text { 定方向性 } \\
\text { 方向交代 }\end{array}$ & 10 & 3 & 5 & 2 & 0 & 0 & 1 \\
\hline 下 向 & 12 & 1 & 4 & 6 & 1 & 2 & 1 \\
\hline 上 向 & 27 & 3 & 19 & 4 & 1 & 0 & 1 \\
\hline 垂 直 性 & 24 & 2 & 17 & 3 & 2 & 2 & 0 \\
\hline 合計 & 86 & 16 & 41 & 19 & 10 & 8 & 12 \\
\hline
\end{tabular}

* 一部重複例を含む 
頭位変換眼振と vs test 結果との関係につい て表 5 に示す．頭位眼振と同様に，頭位変換眼 振の有無とvs との関係は余り明らかではない. 頭位変換眼振のみられない群に急速相障害など による判定不能例が多い点が注目される.

3）視刺激検査と vs test 結果との関係につ いて.

視標追跡検査 $(\mathrm{ETT})$ と vs test 結果との関係 を表 6 に示す. ETT 正常の群では半数におい て vs は正常であった. ETTで saccadic ない しdysmetric pattern を示した群はvsの異常を 高率に示した。検査不能（追従不能）群では全 例が vs の異常を示し，しかもその内容は明所 眼振増強や急速相障害による判定不能であった. ETT の障害とvs の障害とは比例関係にあると
考えられる.

急速眼球運動検查とvs test 結果との関係 を表 7 に示す. 急速眼球運動正常の群では約 40\%の例が vs test 屯正常であった. dysmetric pattern を示した群では90\%の例で vs の異常が 認められた。急速眼球運動の速度低下が認めら れた群では全例が vs の異常を示し，しかむそ の内容は明所眼振増強または判定不能であった. この群では当然のととながら全例で急速相の障 害が認められた。

視運動性眼振検査 (OKP テスト) と vs test 結果との関係を表 8 に示す. OKP 正常または 軽度〜中等度障害の群では, vs は約半数の例で 正常であり，異常はvs の減少〜消失であった. OKP の高度障害や無反応群では大多数の例で

表 5 頭位変換眼振と vs

\begin{tabular}{|c|c|c|c|c|c|c|c|}
\hline \multirow{2}{*}{ 頭位変換眼振 } & & \multicolumn{4}{|c|}{ vs } & \multirow[b]{2}{*}{$\begin{array}{l}\text { 温度反店 } \\
\text { 高度低 }\end{array}$} & \multirow[b]{2}{*}{ 急速相障害 } \\
\hline & 合計 & 正 & 減少～消失 & $\begin{array}{l}\text { 明 所 } \\
\text { 眼振堌強 }\end{array}$ & 判定不能 & & \\
\hline \multirow{2}{*}{$\begin{array}{l}(-) \\
(+)\end{array}$} & 25 & 5 & 5 & 8 & 7 & 6 & 10 \\
\hline & 61 & 11 & 36 & 11 & 3 & 2 & 2 \\
\hline \multirow{3}{*}{$\begin{array}{r}\leftarrow, \rightarrow \\
\frac{\downarrow}{\downarrow}\end{array}$} & 8 & 2 & 3 & 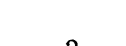 & 0 & 0 & 0 \\
\hline & \multirow{2}{*}{31} & \multirow{2}{*}{6} & \multirow{2}{*}{18} & & \multirow{2}{*}{3} & \multirow{2}{*}{2} & \multirow{2}{*}{1} \\
\hline & & & & 4 & & & \\
\hline$\downarrow$ & \multirow{2}{*}{22} & \multirow{2}{*}{3} & \multirow{2}{*}{16} & \multirow{2}{*}{3} & \multirow{2}{*}{0} & \multirow{2}{*}{0} & \multirow{2}{*}{1} \\
\hline$\uparrow$ & & & & & & & \\
\hline$\uparrow$ & \multirow{2}{*}{1} & \multirow{2}{*}{0} & \multirow{2}{*}{1} & \multirow{2}{*}{0} & \multirow{2}{*}{0} & \multirow{2}{*}{0} & \multirow{2}{*}{0} \\
\hline$\uparrow$ & & & & & & & \\
\hline 計 & 86 & 16 & 41 & 19 & 10 & 8 & 12 \\
\hline
\end{tabular}

表 6 視標追跡検査と vs

\begin{tabular}{|c|c|c|c|c|c|c|c|}
\hline \multirow{2}{*}{$\begin{array}{c}\text { 視標追跡検査 } \\
(\mathrm{ETT})\end{array}$} & \multicolumn{5}{|c|}{ vs } & \multirow[b]{2}{*}{$\begin{array}{l}\text { 温度反応 } \\
\text { 高度低下 }\end{array}$} & \multirow[b]{2}{*}{ 急速相障害 } \\
\hline & 合計 & 常 & 減少～消失 & $\begin{array}{l}\text { 明 豙 } \\
\text { 眼振増強 }\end{array}$ & 判定不能 & & \\
\hline 正 常 & 11 & 6 & 3 & 2 & 0 & $a$ & 2 \\
\hline $\begin{array}{l}\text { 階 段 状 } \\
\text { (saccadic) }\end{array}$ & 62 & 8 & 34 & 14 & 6 & 6 & 4 \\
\hline $\begin{array}{c}\text { 失 調 性 } \\
\text { (dysmetric) }\end{array}$ & 7 & 2 & 4 & 1 & 0 & 0 & 0 \\
\hline 㭘査不能 & 6 & 0 & 0 & 2 & 4 & 2 & 6 \\
\hline 合 & 86 & 16 & 41 & 19 & 10 & 8 & 12 \\
\hline
\end{tabular}


vs の異常が認められ，しかも明所眼振増強や 判定不能の例が多い. 視運動性眼振の障害之 vs の障害とは比例すると考えられる.

以上, 注視眼振の有無, 反撥眼振の有無, 視 標追跡，急速眼球運動，視運動性眼振の異常の 有無之, vs の異常の有無との関連については, いずれも $0.5 \%$ 以下の危険率で統計学的に有意 差が認められた。 しかし，頭位眼振，頭位変換 眼振の有無と,vs の異常の有無との間には有意 差は認められなかった。

\section{考按}

前庭性眼振に対する視覚の関与についての研

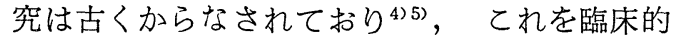
に応用する試みむなされてきだ 〜11)。特に温 度性眼振に対する固視による抑制現象は，眼球 運動の中枢性調節機構の機能検査の一つとして, 臨床に扔いて広く普及してきた。竹森によって 提唱された visual suppression test は，その代 表的な方法であり，その臨床症例における経験 屯十分に蓄積されている ${ }^{122}$ (14). しかし，vs test と他の神経耳科学的検查結果との関連につ いて比較検討した報告は少ない，今回我々はこ
の点を脊䯣小脳変性症症例について検討した.

結論的には, 体平衡, 眼振所見, 視覚刺激に よる眼球運動機能検查 (ETT，OKP， saccade) などの神経耳科学的検査結果と vs test 結果と はよく合致しており, vs test の臨床的有用性に ついて改めて確認されたといえる。

従来の報告に抽いて，vs の減少〜消失は OKP や ETT の障害の軽度のもの，小脳障害 の優位なむのに多くみられ，明所眼振増強は OKP や ETT の障害の高度な脳幹障害の優位 な例に多く，無反応型や測定不能例は長期経過 例や遺伝性の例に多いとされている ${ }^{13) 14)}$ 。本報 告においてあ同様の結果であったが，さらに体 平衡障害, 注視眼振, 反撥眼振, 急速眼球運動 の異常の有無などとの関連も確認された.

vs の異常のうち, vs の減少〜消失之，明所眼 振増強とは機序が異なり，異なった病変部位が 想定されてきた． 即ち，vs の減少〜消失は主と して小脳片葉，明所眼振増強は脳幹とされる 12) 14). 今回の私共の例では，他の神経耳科学 的検査の結果加らり重症度の高いものに明所 眼振増強が多くみられた，春小変という進行性

表 7 急速眼球運動検査と vs

\begin{tabular}{|c|c|c|c|c|c|c|c|c|c|}
\hline \multirow{2}{*}{$\begin{array}{l}\text { 急速眼球 } \\
\text { 運動検査 }\end{array}$} & & & \multicolumn{5}{|c|}{ vs } & \multirow[b]{2}{*}{$\begin{array}{l}\text { 温度反店 } \\
\text { 高度低下 }\end{array}$} & \multirow[b]{2}{*}{ 急速相障害 } \\
\hline & 合 & & 正 & 常 & 減少～消失 & $\begin{array}{l}\text { 琞 所 } \\
\text { 眼振増強 }\end{array}$ & 判定不能 & & \\
\hline 正常 & & & & & 10 & 3 & 1 & 1 & 0 \\
\hline 失 調 性 & & & & & 30 & 10 & 4 & 3 & 0 \\
\hline 速度低下 & & & & & 1 & 6 & 5 & 4 & 12 \\
\hline 合 & & & & & 41 & 19 & 10 & 8 & 12 \\
\hline
\end{tabular}

表 8 視運動性眼振検査と vs

\begin{tabular}{|c|c|c|c|c|c|c|c|}
\hline \multirow{2}{*}{$\begin{array}{l}\text { 視運動性眼振 } \\
\text { 検且 (OKP) }\end{array}$} & & \multicolumn{4}{|c|}{ vs } & \multirow[b]{2}{*}{$\begin{array}{l}\text { 温度反店 } \\
\text { 度低下 }\end{array}$} & \multirow[b]{2}{*}{ 急速相障害 } \\
\hline & 合計 & 正 & 減少～消失 & $\begin{array}{l}\text { 明 所 } \\
\text { 眼振堌強 }\end{array}$ & 判定不能 & & \\
\hline 常 & 8 & 5 & 3 & 0 & 0 & 0 & 0 \\
\hline 軽～中度障害 & 16 & 7 & 8 & 1 & 0 & 0 & 0 \\
\hline 高 度 障 害 & 38 & 4 & 21 & 11 & 2 & 2 & 3 \\
\hline 無 反 応 & 24 & 0 & 9 & 7 & 8 & 6 & 9 \\
\hline 合計 & 86 & 16 & 41 & 19 & 10 & 8 & 12 \\
\hline
\end{tabular}


